\title{
PENGARUH PEMAHAMAN PERATURAN PERPAJAKAN, KUALITAS LAYANAN FISKUS, TARIF PAJAK DAN SANKSI PERPAJAKAN TERHADAP KEPATUHAN WAJIB PAJAK ORANG PRIBADI
}

\author{
Siti Khodijah, Harry Barli, Wiwit Irawati \\ Universitas Pamulang \\ Email: khodijaharrasyid@gmail.com;dosen01058@unpam.ac.id; \\ wiwitira@unpam.ac.id
}

\begin{abstract}
The problem in this study is whether the understanding of tax regulations, quality of tax services, tax rates and tax sanctions affect individual taxpayer compliance. This study aims to determine the effect of understanding tax regulations, quality of tax services, tax rates and tax sanctions on taxpayer compliance at the Kebayoran Baru Tiga Tax Office, South Jakarta. This type of research is a quantitative method that uses the Slovin formula as a sample, so that the sample obtained is 100 individual taxpayers. Methods of data collection using survey methods, namely the authors distribute questionnaires directly and using google form. This study can explain the independent variables (tax regulations, quality of tax services, tax rates and tax sanctions) that strengthen or weaken the dependent variable (taxpayer compliance). Based on the results of the SPSS test version 25 of the tests that have been carried out, the t test results indicate that understanding of tax regulations and service quality tax authorities have a positive and significant effect on taxpayer compliance. Meanwhile, tax rates and tax sanctions have no significant effect on taxpayer compliance.
\end{abstract}

Keywords: Understanding of Taxation Regulations; Quality of Fiscal Service; Tax Rates; Tax Sanctions, Taxpayer Compliance

\begin{abstract}
Abstrak
Permasalahan dalam penelitian ini adalah apakah pemahaman peraturan perpajakan, kualitas layanan fiskus, tarif pajak dan sanksi perpajakan berpengaruh terhadap kepatuhan wajib pajak orang pribadi. Penelitian ini bertujuan untuk mengetahui pengaruh pemahaman peraturan perpajakan, kualitas layanan fiskus, tarif pajak dan sanksi perpajakan terhadap kepatuhan wajib pajak orang pribadi pada Kantor Pelayanan Pajak Pratama Kebayoran Baru Tiga, Jakarta Selatan. Jenis Penelitian ini merupakan metode kuantitatif yang menggunakan rumus slovin sebagai penentuan sampel, sehingga sampel yang didapat yaitu 100 wajib pajak orang pribadi. Metode pengumpulan data menggunakan metode survey, yaitu penulis menyebarkan kuesioner secara langsung dan menggunakan google form. Penelitian ini dapat menjelaskan variabel independen (pemahaman peraturan
\end{abstract}


perpajakan, kualitas layanan fiskus, tarif pajak dan sanksi perpajakan) yang memperkuat atau memperlemah variabel dependen (kepatuhan wajib pajak). Berdasarkan hasil uji SPSS versi 25 dari pengujian yang telah dilakukan, hasil uji t menunjukkan bahwa pemahaman peraturan perpajakan dan kualitas layanan fiskus berpengaruh positif dan signifikan terhadap kepatuhan wajib pajak. Sedangkan tarif pajak dan sanksi perpajakan tidak berpengaruh signifikan terhadap kepatuhan wajib pajak.

Kata Kunci: Pemahaman Peraturan Perpajakan; Kualitas Layanan Fiskus; Tarif Pajak; Sanksi Perpajakan; Kepatuhan Wajib Pajak

\section{PENDAHULUAN}

Sejak tahun 2018-2020 realisasi penerimaan pajak pada KPP Pratama Kebayoran Baru Tiga dari tahun ke tahun mengalami kenaikan dan penurunan secara signifikan dalam mencapai rencana yang ditetapkan. Jumlah ini terlihat bahwa realisasi pajak yang diterima pada tahun 2018 sebesar 3.133.316.503.677 sedangkan rencana yang ditetapkan sebesar 3.321.108.157.000 sehingga pencapaiannya sebesar $94,35 \%$ berarti tidak mencapai rencana yang ditetapkan. Pada tahun 2019 realisasi pajak yang diterima sebesar 4.352.075.814.204 sedangkan rencana yang ditetapkan sebesar 3.974.252.799.000 sehingga pencapaiannya sebesar $109,51 \%$ berarti mencapai rencana yang ditetapkan. Dan pada tahun 2020 realisasi pajak yang diterima sebesar 3.548.862.953.447 sedangkan rencana yang ditetapkan sebesar 3.848.382.841.000 sehingga pencapaiannya sebesar $92,22 \%$.

\section{Tabel 1. Penerimaan Pajak Pada KPP Pratama Kebayoran Baru Tiga Tahun 2018-2020}

\begin{tabular}{cc}
\hline Tahun & Pencapaian \\
\hline 2018 & $94,35 \%$ \\
2019 & $109,51 \%$ \\
2020 & $92,22 \%$ \\
\hline Sumber: KPP Pratama Kebayoran Baru Tiga
\end{tabular}

Jumlah wajib pajak tedaftar wajib SPT tahunan pada KPP Pratama Kebayoran Baru Tiga tahun 2018-2020 mengalami penurunan secara signifikan. Namun kepatuhan wajib pajak yang melaporkan SPT tahunan tahun 2018-2020 mengalami kenaikan secara signifikan. Hal ini menunjukkan bahwa adanya penurunan wajib pajak terdaftar SPT tahunan, tidak mempengaruhi tingkat kepatuhan wajib pajak dalam menyampaikan SPT tahunan

Kepatuhan wajib pajak dipengaruhi adanya pengetahuan dan pemahaman wajib pajak tentang peraturan perpajakan, kualitas pelayanan yang diberikan secara maksimal akan menambah kenyamanan wajib pajak untuk membayar kewajiban pajak, tarif pajak yang berlaku adil sesuai keadaan perekonomian negara membuat wajib pajak paham dan patuh untuk membayar kewajiban pajak dan sanksi

* Corresponding author's e-mail: dosen01058@unpam.ac.id 184 http://openjournal.unpam.ac.id/index.php/JABI 
perpajakan memberikan ancaman kepada wajib pajak yang tidak membayar kewajiban pajak.

Latar belakang masalah yang dipaparkan, membuat rumusan masalah sebagai berikut: (1) Apakah pemahaman peraturan perpajakan berpengaruh terhadap kepatuhan wajib pajak orang pribadi?; (2) Apakah kualitas layanan fiskus berpengaruh terhadap kepatuhan wajib pajak orang pribadi?; (3) Apakah tarif pajak berpengaruh terhadap kepatuhan wajib pajak orang pribadi?; (4) Apakah sanksi perpajakan berpengaruh terhadap kepatuhan wajib pajak orang pribadi?

\section{KERANGKA TEORITIS DAN PENGEMBANGAN HIPOTESIS}

\section{Teori Atribusi}

Fritz Heider sebagai pencetus teori atribusi, teori atribusi merupakan teori yang menjelaskan tentang perilaku seseorang. Teori ini mengacu tentang bagaimana seseorang menjelaskan penyebab perilaku orang lain atau dirinya sendiri yang akan ditentukan apakah dari internal misalnya sifat, karakter, sikap, dan lainlain ataupun eksternal misalnya tekanan situasi atau keadaan tertentu yang akan memberikan pengaruh terhadap perilaku individu ( (Heider, 1958); (Putri \& Setiawan, 2017)).

Peneliti menggunakan teori atribusi karena peneliti akan melakukan studi kasus pada orang pribadi untuk mengetahui faktor-faktor apa saja yang mempengaruhi kepatuhan wajib pajak orang pribadi. Terhadap faktor internal yaitu pemahaman peraturan perpajakan dari wajib pajak itu sendiri untuk melakukan suatu aktivitas perpajakannya dan faktor eksternal yaitu kualitas pelayananan, tarif pajak dan sanksi perpajakan, khususnya pada karakteristik aparat pajak.

\section{Kepatuhan Wajib Pajak}

Kepatuhan perpajakan merupakan ketaatan, tunduk dan patuh serta melaksanakan ketentuan perpajakan. Jadi wajib pajak yang patuh adalah wajib pajak yang taat dan memenuhi serta melaksanakan kewajiban perpajakannya dengan ketentuan perundang-undangan perpajakan ((Irawati \& Sari, 2019). Kepatuhan perpajakan juga dapat didefinisikan sebagai suatu keadaan di mana wajib pajak memenuhi semua kewajiban perpajakan dan melaksanakan hak perpajakannya, (Pohan, 2014). Indikator kepatuhan wajib pajak yang digunakan dalam penelitian ini mengacu pada penelitian Hamzah dkk. (2018) yaitu:

a. Melaporkan SPT secara berkala dan tertib

b. Menghitung sendiri pajak yang terutang

c. Melakukan pembayaran sesuai jadwal waktu yang ditetapkan dalam undangundang dan

d. Transparan melaporkan obyek pajaknya.

\section{Pemahaman Peraturan Perpajakan terhadap Kepatuhan Wajib Pajak Orang Pribadi}

Pemahaman wajib pajak merupakan proses di mana wajib pajak mengetahui tentang perpajakan dan mengaplikasikannya untuk membayar pajak,

* Corresponding author's e-mail: dosen01058@unpam.ac.id 
(Dewi dan Sumaryanto, 2019). Indikator pemahaman peraturan perpajakan yang digunakan dalam penelitianini mengacu pada penelitian Priambodo (2017) yaitu:

a. Mempunyai pengetahuan mengenai ketentuan umum dan tata cara perpajakan

b. Mempunyai pengetahuan mengenai sistem perpajakan di Indonesia

c. Mempunyai pengetahuan mengenai fungsi perpajakan.

Asfa dan Meiranto (2017) menyatakan bahwa pengetahuan dan pemahaman perpajakan berpengaruh positif dan signifikan terhadap kepatuhan wajib pajak orang pribadi. Lazuardini, dkk. (2018) menyimpulkan bahwa pemahaman peraturan perpajakan mempunyai pengaruh positif dan signifikan pada ketaatan wajib pajak orang pribadi. Semakin tinggi pemahaman peraturan perpajakan, maka semakin tinggi juga ketaatan wajib pajak orang pribadi. Semakin besar dan tinggi tingkat pengetahuan dan pemahaman perpajakannya, maka semakin tinggi pula tingkat kepatuhan wajib pajak orang pribadi. Raharjo dkk. (2020) bahwa wajib pajak disarankan untuk meng-update pengetahuan mengenai peraturan perpajakan, karena masih dijumpai wajib pajak yang kurang mengetahui kapan batas akhir waktu untuk melaporkan SPT sehingga wajib pajak dapat melaporkan SPT tepat pada waktu yang ditentukan.

H1: Diduga Pemahaman Peraturan Perpajakan berpengaruh terhadap Kepatuhan Wajib Pajak Orang Pribadi.

\section{Kualitas Layanan Fiskus terhadap Kepatuhan Wajib Pajak Orang Pribadi}

Kualitas layanan fiskus merupakan kualitas dari cara aparat pajak melayani wajib pajak, dengan pelayanan yang diberikan secara maksimal akan berkaitan pada tingkat kepatuhan wajib pajak (Asfa dan Meiranto, 2017). Indikator kualitas pelayanan fiskus yang digunakan dalam penelitian ini mengacu pada penelitian Hamzah dkk. (2018) yaitu:

a. Memberikan layanan sebaik mungkin

b. Tarif pajak ditetapkan dengan tepat dan benar

c. Fiskus memberikan penjelasan atas pertanyaan wajib pajak

d. Fiskus memperhatikan keberatan setiap wajib pajak dan

e. Fiskus memberikan penyuluhan tentang prosedur perpajakan.

Halawa dan Saragih (2017) menyatakan bahwa sikap fiskus berpengaruh positif dan signifikan terhadap kepatuhan wajib pajak. Sikap fiskus yang profesional dalam bekerja membuat wajib pajak merasa nyaman dan percaya dalam membayar kewajiban pajaknya sehingga kepatuhan wajib pajak meningkat. Tene dkk. (2017) menyimpulkan bahwa Pelayanan fiskus tidak berpengaruh signifikan terhadap kepatuhan wajib pajak di KPP Pratama Manado. Perlunya perbaikan dan peningkatan pelayanan dari petugas fiskus untuk memenuhi hak dan kewajibannya sehingga wajib pajak sadar untuk memenuhi kewajiban pajaknya. Pelayanan fiskus berpengaruh positif terhadap kepatuhan wajib pajak. Semakin baik tingkat pelayanan fiskus maka akan semakin meningkat kepatuhan wajib pajak dalam membayar pajaknya dan begitu juga sebaliknya.

H2: Diduga Kualitas Layanan Fiskus tidak berpengaruh terhadap Kepatuhan Wajib Pajak Orang Pribadi.

* Corresponding author's e-mail: dosen01058@unpam.ac.id 


\section{Tarif Pajak terhadap Kepatuhan Wajib Pajak Orang Pribadi}

Tarif pajak adalah suatu penetapan atau persentase berdasarkan undangundang yang dapat digunakan untuk menghitung dan/atau menentukan jumlah pajak yang harus dibayar, disetor dan/atau dipungut oleh wajib pajak (Tawas dkk., 2016). Indikator tarif pajak yang digunakan dalam penelitian ini mengacu pada penelitian (Suhendri, 2015 dalam Suarni dan Marlina, 2018) yaitu:

a. Tarif pajak yang dikenakan secara proporsional atau dikenakan sesuai dengan tingkat penghasilan

b. Tarif pajak yang adil berarti harus sama setiap wajib pajak.

Suarni dan Marlina (2018) menyimpulkan bahwa tarif pajak tidak berpengaruh signifikan terhadap kepatuhn wajib paja orang pribadi di KPP Pratama Padang Satu. Menurutnya besar kecilnya tarif pajak tidak mempengaruhi kepatuhan wajib pajak dalam membayar pajak, dikarenakan tarif pajak sudah ditetapkan oleh pemerintah yang harus dipatuhi, dan apabila melanggarnya akan dikenakan sanksi yang berlaku. Tarif pajak mempunyai pengaruh positif dan signifikan pada ketaatan wajib pajak orang pribadi. Semakin adil tarif pajak yang diberikan, akan semakin meningkat ketaatan wajib pajak orang pribadi

Dewi dan Sumaryanto (2019) menyatakan bahwa tarif pajak berpengaruh positif terhadap kepatuhan wajib pajak. Berdasarkan hasil yang diperoleh, menunjukkan bahwa kepatuhan wajib pajak dipengaruhi oleh tarif pajak yang berlaku. Penetapan tarif pajak sektor batik di Kota Yogyakarta tergolong sudah adil dan sesuai. Semakin adil tarif pajak yang dikenakan maka akan semakin meningkat kepatuhan wajib pajak dalam membayar pajak.

\section{H3: Diduga Tarif Pajak berpengaruh terhadap Kepatuhan Wajib Pajak Orang Pribadi.}

\section{Sanksi Perpajakan terhadap Kepatuhan Wajib Pajak Orang Pribadi}

Sanksi perpajakan merupakan alat pencegah agar wajib pajak tidak melanggar aturan perpajakan. Sanksi akan diberikan pada wajib pajak yang tidak patuh dengan aturan yang berlaku. Sanksi perpajakan meliputi sanksi administrasi dan sanksi pidana. Semakin tinggi sanksi yang berlaku, maka wajib pajak diharapkan akan semakin peduli terhadap kewajiban perpajakannya (Asfa dan Meiranto, 2017). Indikator sanksi perpajakan yang digunakan dalam penelitian ini mengacu pada penelitian (Mutia, 2014 dalam Farah dan Sapari, 2020) yaitu:

a. Sanksi diberikan untuk keterlambatan pembayaran pajak terutang

b. Sanksi diberikan sesuai dengan pelanggaran yang dilakukan

c. Penerapan sanksi harus sesuai dengan ketentuan dan peraturan yang berlaku

d. Sanksi diperlukan untuk menciptakan kedisipilinan WP dalam membayar pajak.

Lazuardini dkk. (2018) menyatakan bahwa sanksi pajak berpengaruh negatif dan tidak signifikan terhadap kepatuhan wajib pajak. Semakin tegas sanksi maka ketaatan wajib pajak orang pribadi yang terdaftar di KPP Pratama Malang Selatan akan turun. Dewi dan Sumaryanto (2019) menyatakan bahwa sanksi perpajakan berpengaruh positif terhadap kepatuhan wajib pajak. Dengan adanya ketegasan sanksi perpajakan, maka wajib pajak akan mematuhi peraturan perpajakan yang 
telah ditetapkan. Wajib pajak menyadari peraturan dan sanksi yang diterima apabila tidak memenuhi kewajiban perpajakannya. Dapat disimpulkan bahwa semakin tegas sanksi yang diberikan, maka semakin meningkat kepatuhan wajib pajak.

H4: Diduga Sanksi Perpajakan berpengaruh terhadap Kepatuhan Wajib Pajak Orang Pribadi.

\section{METODE RISET}

Penelitian berlokasi di Kantor Pelayanan Pajak Pratama Kebayoran Baru Tiga di Jalan K.H Ahmad Dahlan No.14 A Jakarta Selatan 12130, dengan populasi dalam penelitian ini sebanyak 18.308 wajib pajak orang pribadi yang berada di lingkungan kantor pelayanan pajak (KPP) Pratama Kebayoran Baru Tiga. Sampel yang merupakan bagian dari jumlah dan karakteristik yang dimiliki oleh populasi dalam penelitian ini ditentukan dengan menggunakan rumus Slovin yaitu:

$\mathrm{n}=\mathrm{N}:\left(1+\mathrm{Ne}^{2}\right)$, dengan error margin $10 \%, \mathrm{n}=$ jumlah sampel dan $\mathrm{N}=$ jumlah populasi penelitian, yang menghasilkan $n=100$ responden, (Kusumayanthi dan Suprasto, 2019)

\section{Metode Pengumpulan Data}

Data diperoleh dengan menggunakan angket atau kuesioner pada responden. Menurut Sugiyono (2016:142) “Kuesioner merupakan teknik pengumpulan data yang dilakukan dengan cara memberi seperangkat pertanyaan atau pernyataan tertulis kepada responden untuk dijawabnya”.

Pembagian kuesioner atau angket dilakukan oleh peneliti kepada wajib pajak di KPP Pratama Kebayoran Tiga Baru baik secara langsung atau dengan google form.

Penelitian ini semua instrumen menggunakan skala likert dengan lima skala yaitu (Sugiyono, 2016:94).

\begin{tabular}{llc}
\hline Kode & \multicolumn{1}{c}{ Keterangan } & Skor \\
\hline SS & Sangat Setuju & 5 \\
S & Setuju & 4 \\
N & Netral & 3 \\
TS & Tidak Setuju & 2 \\
STS & Sangat Tidak Setuju & 1 \\
\hline
\end{tabular}

\section{Metode Analisis Data}

Analisis data adalah proses mencari dan menyusun secara sistematis data yang diperoleh dari hasil wawancara, catatan lapangan, dokumentasi, dengan cara mengorganisasikan data ke dalam kategori, menjabarkan ke dalam unit-unit, melakukan sintesa, menyusun ke dalam pola, memilih mana yang penting dan yang

* Corresponding author's e-mail: dosen01058@unpam.ac.id

http://openjournal.unpam.ac.id/index.php/JABI 
akan dipelajari dan membuat kesimpulan sehingga mudah dipahami oleh diri sendiri maupun orang lain, (Sugiyono, 2016).

Olah data menggunakan alat bantu SPSS versi 16, yang dimulai dengan pengujian kualitas Instrument penelitian menggunakan Uji validitas dan Uji Reliabilitas. Valid berarti instrumen tersebut dapat digunakan untuk mengukur apa yang seharusnya diukur. Sedangkan Uji reliabilitas digunakan untuk mengukur beberapa kali obyek yang sama dan akan menghasilkan data yang sama, (Sugiyono, 2016).

Data penelitian kemudian diuji kualitasnya menggunakan Uji Asumsi Klasik, yang terdiri dari Uji Normalitas yang bertujuan untuk menguji apakah dalam model regresi, variabel pengganggu atau residual memiliki distribusi normal dan model regresi yang baik adalah yang memiliki distribusi normal atau mendekati normal, Uji Multikolinearitas yang bertujuan untuk menguji apakah model regresi ditemukaan adanya kolerasi antar variabel bebas, dan Uji Heteroskedastisitas yang bertujuan menguji apakah dalam model regresi terjadi ketidaksamaan antara variance dari residual satu pengamatan ke pengamatan lain, (Ghozali, 2018).

Data yang lolos kemudian diiuji Statistik Deskriptif untuk melihat nilai rata-rata, nilai minimum dan nilai maksimumnya, kemudian Uji Hipotesis menggunakan Uji Regresi Linier Berganda untuk mendapatkan hasil Uji t, Uji F dan nilai Koefisien Determinasinya.

\section{ANALISIS DATA DAN PEMBAHASAN}

Responden dalam penelitian ini adalah wajib pajak orang pribadi di KPP Pratama Kebayoran Baru Tiga. Hal ini sesuai dengan metode pengambilan sampel yaitu Convenience Sampling atau dapat diartikan penentuan sampel berdasarkan kebetulan, yaitu siapa saja yang kebetulan bertemu dengan penelitia dan dapat digunakan sebagai sampel, sesuai kriteria yang dapat dijadikan sebagai sumber data, dan dihasilkan 100 responden.

Tabel 2 Distribusi Kuesioner dan Pengumpulan Data

\begin{tabular}{lc}
\hline \multicolumn{1}{c}{ Keterangan } & Hasil \\
\hline Jumlah kuesioner yang disebar manual & 50 \\
Jumlah kuesioner yang terisi melalui google form & 50 \\
Jumlah kuesioner yang diolah & 100 \\
Presentase & $100 \%$ \\
\hline
\end{tabular}

Sumber: diolah oleh penulis, 2021

\section{Uji Statistik Deskriptif}

Statistik deskriptif memberikan gambaran atau deskriptif suatu data yang pada penelitian ini dilihat dari nilai rata-rata (mean), standar deviasi, maksimum, minimum. 
Jurnal Akuntansi Berkelanjutan Indonesia - Vol. 4, No. 2, Mei 2021 - Khodijah, Barli \& Irawati

Tabel 3 Hasil Analisis Statistik Deskriptif

\begin{tabular}{lccccc}
\hline & N & Min & Max & Mean & Std. Deviation \\
\hline Pemahaman Peraturan Perajakan (X1) & 100 & 17.00 & 40.00 & 26.9100 & 6.40564 \\
Kualitas Layanan Fiskus (X2) & 100 & 16.00 & 40.00 & 26.5100 & 7.94361 \\
Tarif Pajak (X3) & 100 & 13.00 & 40.00 & 26.9900 & 4.34264 \\
Sanksi Perpajakan (X4) & 100 & 12.00 & 40.00 & 30.8000 & 4.59248 \\
Kepatuhan Wajib Pajak (Y) & 100 & 23.00 & 40.00 & 31.2900 & 3.51129 \\
\hline
\end{tabular}

Sumber: Output SPSS 25

\section{Uji Koefisien Determinasi $\left(\mathbf{R}^{\mathbf{2}}\right)$}

Koefisien Determinasi $\left(\mathrm{R}^{2}\right)$ pada dasarnya digunakan untuk mengukur seberapa besar variasi dari variabel independen mampu menjelaskan variansi dari variabel dependen.

Tabel 4 Hasil Uji Koefisien Determinasi $\left(\mathbf{R}^{2}\right)$

\begin{tabular}{|c|c|c|c|c|}
\hline Model & $\mathrm{R}$ & R Square & $\begin{array}{l}\text { Adjusted } \\
R \text { Square }\end{array}$ & $\begin{array}{l}\text { Std. Error of the } \\
\text { Estimate }\end{array}$ \\
\hline 1 & $.673^{\mathrm{a}}$ & .453 & .430 & 2.65025 \\
\hline
\end{tabular}

Hasil perhitungan analisis model koefisien determinasi $\left(\mathrm{R}^{2}\right)$ di atas dapat diartikan bahwa angka $\mathrm{R}$ Square sebesar 0,453, yang berarti menunjukkan bahwa hubungan antara variabel dependen dan variabel independen adalah kuat karena angka tersebut lebih besar dari 0,05. Sedangkan Adjusted $R$ Square sebesar 0,430 atau sama dengan $43 \%$, hal tersebut dapat diartikan bahwa sebesar $43 \%$ pengaruh kepatuhan wajib pajak dapat dijelaskan oleh variabel pemahaman peraturan perpajakan, kualitas layanan fiskus, tarif pajak dan sanksi perpajakan sedangkan sisanya sebesar 57\% dapat dijelaskan oleh faktor-faktor penyebab lainnya yang tidak terdapat dalam penelitian ini.

\section{Uji Signifikansi Simultan (Uji F)}

Uji statistik $\mathrm{F}$ bertujuan untuk mengetahui apakah variabel independen secara bersama-sama berpengaruh terhadap variabel dependen. Apabila $F_{\text {hitung }}>$ $F_{\text {tabel }}$ dan nilai signifikannya lebih kecil dari 0,05 maka dapat dikatakan bahwa ada pengaruh yang signifikan antara variabel bebas dan variabel terikat secara simultan.

Tabel 5 Hasil Uji Signifikansi Simultan (Uji F)

\begin{tabular}{lrrrrr}
\hline Model & Sum of Squares & \multicolumn{1}{c}{ Df } & Mean Square & F & \multicolumn{1}{c}{ Sig. } \\
\hline Regression & 553.325 & 4 & 138.331 & 19.695 & $.000^{\mathrm{b}}$ \\
Residual & 667.265 & 95 & 7.024 & & \\
Total & 1220.590 & 99 & & & \\
a. Dependent Variable: Kepatuhan Wajib Pajak & & & \\
\hline
\end{tabular}

* Corresponding author's e-mail: dosen01058@unpam.ac.id

http://openjournal.unpam.ac.id/index.php/JABI 


\section{, Sanksi Perpajakan, Kualitas layanan Fiskus, Pemahaman Peraturan Perpajakan, $\mathrm{T}$ Sumber: Output SPSS 25}

Berdasarkan tabel di atas menunjukkan bahwa nilai $\mathrm{F}_{\text {hitung }}$ sebesar 19,695 dengan tingkat signifikannya 0,000 . Untuk mencari $F_{\text {tabel }}$ dengan jumlah sampel $(n)=100$, jumlah variabel $(k)=4$, taraf signifikannya $(\alpha)=0,05$ maka $d f=n-k=100$ 4=96. Dengan menggunakan tabel distribusi $\mathrm{F}$ dan taraf signifikansi 0,05 diperoleh nilai $F_{\text {tabel }}$ sebesar 2,47. Diketahui nilai $F_{\text {hitung }}$ sebesar 19,695 dan nilai $F_{\text {tabel }}$ sebesar 2,47. Jadi nilai $F_{\text {hitung }}$ sebesar 19,695 > nilai $F_{\text {tabel }}$ sebesar 2,47 dengan tingkat signifikannya $0,000<0,05$. Dapat disimpulkan bahwa Pemahaman Peraturan Perpajakan (X1), Kualitas Layanan Fiskus (X2), Tarif Pajak (X3) dan Sanksi Perpajakan (X4) berpengaruh signifikan terhadap Kepatuhan Wajib Pajak Orang Pribadi (Y), sehingga model persamaan regresi diterima.

\section{Uji Signifikansi Parsial (Uji t)}

Uji t dilakukan untuk mengetahui apakah variabel independen secara parsial berpengaruh signifikan dengan variabel dependen. Uji t dilakukan dengan cara membandingkan antara nilai probabilitas dengan nilai tingkat signifikan. Jika nilai signifikan $<0,05$ maka $\mathrm{H}_{0}$ diterima dan jika nilai signifikan $>0,05$ maka $\mathrm{H}_{0}$ ditolak.

Tabel 6 Hasil Uji Signifikansi Parsial (Uji t)

\begin{tabular}{|c|c|c|c|c|c|}
\hline \multirow[b]{2}{*}{ Model } & \multicolumn{2}{|c|}{$\begin{array}{l}\text { Unstandardized } \\
\text { Coefficients }\end{array}$} & \multirow{2}{*}{$\begin{array}{c}\text { Standardized } \\
\text { Coefficients } \\
\text { Beta }\end{array}$} & \multirow[b]{2}{*}{$\mathrm{t}$} & \multirow[b]{2}{*}{ Sig. } \\
\hline & B & Std. Error & & & \\
\hline (Constant) & 16.988 & 1.963 & & 8.652 & .000 \\
\hline $\begin{array}{l}\text { Pemahaman Peraturan } \\
\text { Perpajakan (X1) }\end{array}$ & .226 & .053 & .412 & 4.228 & .000 \\
\hline Kualitas Layanan Fiskus (X2) & .121 & .038 & .273 & 3.164 & .002 \\
\hline Tarif Pajak (X3) & .002 & .106 & .003 & .023 & .982 \\
\hline $\begin{array}{l}\text { Sanksi Perpajakan (X4) } \\
\text { a. Dependent Variable: Kepatt }\end{array}$ & $\begin{aligned} .161 \\
\text { Vajib Paj }\end{aligned}$ & .085 & .211 & 1.907 & .060 \\
\hline
\end{tabular}

Diketahui bahwa jumlah sampelyang diteliti $(\mathrm{n})=100$, $\operatorname{taraf} \operatorname{signifikan}(\alpha)=$ 0,05 dan derajat bebas (degree of freedom) $\mathrm{df}=\mathrm{n}-\mathrm{k}=100-4=96$. Dengan menggunakan tabel distribusi $\mathrm{t}$ dan taraf signifikansi 0,05 diperoleh nilai $\mathrm{t}_{\text {tabel }}$ sebesar 1,984. Dari tabel 4.16 dapat dijelaskan hasil pengujian secara parsial sebagai berikut.

Variabel pemahaman peraturan perpajakan (X1) memiliki nilai $t_{\text {hitung }}$ sebesar 4,228 dengan signifikansi 0,000. Jadi nilai thitung sebesar 4,228 $>t_{\text {tabel }}$ sebesar 1,984 dan tingkat signifikansi $0,000<0,05$. Dapat disimpulkan bahwa variabel pemahaman peraturan perpajakan secara parsial berpengaruh terhadap kepatuhan wajib pajak, $\mathrm{H}_{1}$ diterima.

Variabel kualitas layanan fiskus (X2) memiliki nilai thitung sebesar 3,164 dengan signifikansi 0,002. Jadi nilai $t_{\text {hitung }}$ sebesar 3,164 $>t_{\text {tabel }}$ sebesar 1,984 dan tingkat signifikansi $0,002<0,05$. Dapat disimpulkan bahwa variabel kualitas

* Corresponding author's e-mail: dosen01058@unpam.ac.id 
Jurnal Akuntansi Berkelanjutan Indonesia - Vol. 4, No. 2, Mei 2021 - Khodijah, Barli \& Irawati

layanan fiskus secara parsial berpengaruh terhadap kepatuhan wajib pajak, $\mathrm{H}_{2}$ diterima.

Variabel tarif pajak (X3) memiliki nilai thitung sebesar 0,023 dengan

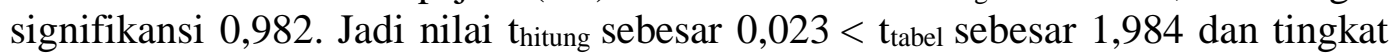
signifikansi $0,982>0,05$. Dapat disimpulkan bahwa variabel tarif pajak secara parsial tidak berpengaruh terhadap kepatuhan wajib pajak, $\mathrm{H}_{3}$ ditolak.

Variabel sanksi perpajakan (X4) memiliki nilai thitung sebesar 1,907 dengan signifikansi 0,060 . Jadi nilai $t_{\text {hitung }}$ sebesar $1,907<t_{\text {tabel }}$ sebesar 1,984 dan tingkat signifikansi $0,060>0,05$. Dapat disimpulkan bahwa variabel kualitas sanksi perpajakan secara parsial tidak berpengaruh terhadap kepatuhan wajib pajak, $\mathrm{H}_{4}$ ditolak.

\section{Pengaruh Pemahaman Peraturan Perpajakan terhadap Kepatuhan Wajib Pajak Orang Pribadi}

Pengujian yang dilakukan terhadap pengaruh pemahaman peraturan perpajakan terhadap kepatuhan wajib pajak diperoleh hasil bahwa nilai thitung sebesar 4,228 $>t_{\text {tabel }}$ sebesar 1,984 dan tingkat signifikansi $0,000<0,05$. Dapat dikatakan bahwa variabel pemahaman peraturan perpajakan berpengaruh positif terhadap kepatuhan wajib pajak. Dengan demikian $\mathrm{H}_{1}$ dalam penelitian ini diterima. Hasil penelitian ini sejalan dengan penelitian sebelumnya yang dilakukan oleh Dewi dan Sumaryanto (2019) yang mendapat hasil bahwa pemahaman wajib pajak berpengaruh positif terhadap kepatuhan wajib pajak. Karena dengan adanya pemahaman peraturan perpajakan wajib pajak mengetahui akan hak dan kewajibannya dalam membayar pajak sehingga kepatuhan wajib pajak meningkat.

\section{Pengaruh Kualitas Layanan Fiskus terhadap Kepatuhan Wajib Pajak Orang Pribadi}

Pengujian yang dilakukan terhadap pengaruh kualitas layanan fiskus terhadap kepatuhan wajib pajak diperoleh hasil bahwa nilai thitung sebesar 3,164> $\mathrm{t}_{\text {tabel }}$ sebesar 1,984 dan tingkat signifikansi 0,002 <0,05. Dapat dikatakan bahwa variabel kualitas layanan fiskus berpengaruh positif terhadap kepatuhan wajib pajak. Dengan demikian $\mathrm{H}_{2}$ dalam penelitian ini diterima. Hasil penelitian ini sejalan dengan penelitian sebelumnya yang dilakukan oleh Asfa dan Meiranto (2017) yang mendapat hasil bahwa pelayanan fiskus berpengaruh positif dan signifikan terhadap kepatuhan wajib pajak. Karena dengan kualitas layanan fiskus yang maksimal membuat wajib pajak merasa nyaman, percaya dan terbantu dalam membayar kewajiban pajaknya sehingga kepatuhan wajib pajak meningkat. Sebaliknya jika kualitas layanan fiskus kurang maksimal maka wajib pajak merasa tidak nyaman dan tidak puas dalam membayar kewajiban pajaknya sehingga kepatuhan wajib pajak menurun.

\section{Pengaruh Tarif Pajak terhadap Kepatuhan Wajib Pajak Orang Pribadi}

Pengujian yang dilakukan terhadap pengaruh tarif pajak terhadap kepatuhan wajib pajak diperoleh hasil bahwa nilai $t_{\text {hitung }}$ sebesar $0,023<\mathrm{t}_{\text {tabel }}$ sebesar 1,984 dan tingkat signifikansi 0,982 >0,05. Dapat dikatakan bahwa variabel tarif pajak tidak berpengaruh terhadap kepatuhan wajib pajak. Dengan demikian $\mathrm{H}_{3}$

* Corresponding author's e-mail: dosen01058@unpam.ac.id 
dalam penelitian ini ditolak. Hasil penelitian ini sejalan dengan penelitian sebelumnya yang dilakukan oleh Suarni dan Marlina (2018) yang mendapat hasil bahwa tarif pajak tidak berpengaruh signifikan terhadap kepatuhan wajib pajak. Karena tarif pajak yang berlaku sudah adil sesuai ketetapan pemerintah yang disesuaikan dengan penghasilan wajib pajak sehingga tarif pajak tidak berpengaruh terhadap kepatuhan wajib pajak.

\section{Pengaruh Sanksi Perpajakan terhadap Kepatuhan Wajib Pajak Orang Pribadi}

Pengujian yang dilakukan terhadap pengaruh sanksi perpajakan terhadap kepatuhan wajib pajak diperoleh hasil bahwa nilai $t_{\text {hitung }}$ sebesar $1,907<t_{\text {tabel }}$ sebesar 1,984 dan tingkat signifikansi $0,060>0,05$. Dapat dikatakan bahwa variabel kualitas sanksi perpajakan secara tidak berpengaruh terhadap kepatuhan wajib pajak. Dengan demikian $\mathrm{H}_{4}$ dalam penelitian ini ditolak. Hasil penelitian ini sejalan dengan penelitian sebelumnya yang dilakukan oleh Muhamad, dkk. (2019) yang mendapat hasil bahwa sanksi perpajakan tidak berpengaruh terhadap kepatuhan wajib pajak.

\section{KESIMPULAN DAN SARAN}

Berdasarkan penelitian yang dilakukan dapat ditarik beberapa simpulan sebagai berikut:

1. Pemahaman Peraturan Perpajakan berpengaruh positif terhadap Kepatuhan Wajib Pajak Orang Pribadi di Kantor Pelayanan Pajak Pratama Kebayoran Baru Tiga.

2. Kualitas Layanan Fiskus berpengaruh positif terhadap Kepatuhan Wajib Pajak Orang Pribadi di Kantor Pelayanan Pajak Pratama Kebayoran Baru Tiga.

3. Tarif Pajak tidak berpengaruh terhadap Kepatuhan Wajib Pajak Orang Pribadi di Kantor Pelayanan Pajak Pratama Kebayoran Baru Tiga. Karena tarif pajak yang berlaku sudah adil sesuai ketetapan pemerintah yang disesuaikan dengan penghasilan wajib pajak sehingga tarif pajak tidak berpengaruh terhadap kepatuhan wajib pajak.

4. Sanksi Perpajakan tidak berpengaruh terhadap Kepatuhan Wajib Pajak Orang Pribadi di Kantor Pelayanan Pajak Pratama Kebayoran Baru Tiga.

\section{Saran}

Peneliti mengemukakan beberapa saran sebagai berikut:

1. Bagi peneliti selanjutnya yang tertarik untuk melakukan kajian di bidang yang sama dapat menggunakan variabel independen yang tidak digunakan dalam penelitian ini, sehingga ditemukan yang dapat mempengaruhi, memperkuat atau memperlemah variabel dependen (Kepatuhan Wajib Pajak).

2. Tarif pajak yang berlaku harus adil sesuai dengan ketentuan peraturan perpajakan dan disesuaikan dengan penghasilan wajib pajak sehingga kepatuhan wajib pajak meningkat.

3. Sanksi perpajakan harus tegas agar wajib pajak patuh dalam membayar kewajiban pajaknya sehingga kepatuhan wajib pajak meningkat.

* Corresponding author's e-mail: dosen01058@unpam.ac.id 
Jurnal Akuntansi Berkelanjutan Indonesia - Vol. 4, No. 2, Mei 2021 - Khodijah, Barli \& Irawati

\section{DAFTAR PUSTAKA}

Amalia, D. C. (2018). Pengaruh Pelaksanaan Pemeriksaan Pajak, Sanksi Pajak dan Tingkat Pemahaman Perpajakan terhadap Kepatuhan Wajib Pajak Orang Pribadi. Jakarta: Universitas Muhammadiyah Jakarta.

Asfa, E. R., \& Meiranto, W. (2017). Pengaruh Sanksi Perpajakan, Pelayanan Fiskus, Pengetahuan dan Pemahaman, Kesadaran Perpajakan terhadap Kepatuhan Wajib pajak. Diponegoro Journal Of Accounting, ISSN (Online): 2337-3806 Vol. 6 No. 3 Tahun 2017 Hal. 1-13.

Dewi, N. A., \& Jati, I. K. (2018). Pengaruh Sosialisasi, Kualitas Pelayanan, Sanksi dan Biaya Kepatuhan pada Tingkat Kepatuhan Wajib Pajak kendaraan Bermotor. e-Jurnal Akuntansi, ISSN: 2302-8556 Vol. 25.1.Oktober (2018): 1-30 .

Dewi, N. T., \& Sumaryanto. (2019). Pengaruh Kesadaran Wajib Pajak, Pemahaman Wajib Pajak, Kualitas Pelayanan, Tarif Pajak dan Sanksi Perpajakan terhadap Kepatuhan Wajib Pajak. Jurnal Akuntansi , 1-12.

Farah, R. N. (2020). Pengaruh Penerapan e-Filling, Sosialisasi Perpajakan dan Sanksi Perpajakan terhadap Kepatuhan Wajib Pajak Orang Pribadi. Jurnal Ilmu dan Riset Akuntansi, e-ISSN: 2460-0585 Vol. 9 No. 3 Maret 2020 Hal. 1-21.

Ghozali, I. (2018). Aplikasi Analisis, Multivariate dengan Program IBM SPSS 25 (Edisi 9). Semarang: Badan Penerbit Universitas Diponegoro.

Halawa, J., \& Saragih, J. L. (2017). Pengaruh Kesadaran Perpajakan, Sanksi Pajak, Sikap Fiskus terhadap Kepatuhan Wajib di KPP Pratama Lubuk Pakam. JRAK, ISSN : 2443-1079 Vol. 3 No. 2 September 2017 Hal. 243-256.

Heider, F. (1958). The psychology of interpersonal relations: Psychology Press.

Hamzah, M. F., Ramdani, M. R., Muslim, \& Putra, A. H. (2018). Faktor-Faktor yang Mempengaruhi Kepatuhan Wajib Pajak. Journal of Institution Sharia Finance, ISSN: 2620-5130 Vol. 1 No. 1 Juni 2018 Hal. 175-184.

Irawati, W., \& Sari, A. K. (2019). Pengaruh persepsi wajib pajak dan preferensi risiko terhadap kepatuhan wajib pajak. Jurnal Akuntansi Barelang 3(2), 104-114.

Kusumayanthi, L. O., \& Suprasto, H. B. (2019). Pengaruh Penerapan e-Filling, Sosialisasi Perpajakan, Kinerja Account Representative dan Sanksi Pajak terhadap Kepatuhan Wajib Pajak Orang Pribadi. e-Jurnal Akuntansi, ISSN: 2302-8556 Vol. 28 No. 1 Juli (2019) Hal. 491-518.

Lazuardini, E. R., Susyanti, J., \& Priyono, A. A. (2018). Pengaruh Pemahaman Peraturan Perpajakan, Tarif Pajak dan Sanksi Pajak terhadap Kepatuhan Wajib Pajak UMKM. e-Journal Riset Manajemen, 25-34.

* Corresponding author's e-mail: dosen01058@unpam.ac.id http://openjournal.unpam.ac.id/index.php/JABI 
Jurnal Akuntansi Berkelanjutan Indonesia - Vol. 4, No. 2, Mei 2021 - Khodijah, Barli \& Irawati

Mardiasmo. (2018). Perpajakan Edisi Terbaru 2018. Yogyakarta: ANDI.

Muhamad, M. S., Asnawi, M., \& Pangayaw, B. J. (2019). Pengaruh Sosialisasi Perpajakan, Tarif Pajak, Sanksi Perpajakan dan Kesadaran Perpajakan terhadap Kepatuhan Pelaporan SPT Tahunan Wajib Pajak Orang Pribadi. Jurnal Akuntansi dan Keuangan Daerah, Vol. 14 No. 1 Mei 2019 Hal. 6986.

Pohan, C. A. (2014). Pembahasan komprehensif pengantar perpajakan. Jakarta: Mitra Wacana Media.

Priambodo, P. (2017). Pengaruh Pemahaman Peraturan Pajak, Sanksi Perpajakan dan Kesadaran Wajib Pajak terhadap Kepatuhan Wajib Pajak Orang Pribadi di KPP Pratama Kabupaten Purworejo. Yogyakarta: Universitas Negeri Yogyakarta.

Putri, K. J., \& Setiawan, P. E. (2017). Pengaruh Kesadaran, Pengetahuan Dan Pemahaman Perpajakan, Kualitas Pelayanan Dan Sanksi Perpajakan Terhadap Kepatuhan Wajib Pajak. E-Jurnal Akuntansi Universitas Udayana, 18(2), 1112-1140.

Raharjo, N. K., Majidah, \& Kurnia. (2020). Pengaruh Pemahaman Peraturan Perpajakan, Tarif Pajak dan Kualitas Pelayanan terhadap Kepatuhan Wajib Pajak. e-Jurnal Ekonomi dan Bisnis, ISSN: 2337-3067 (2020) Hal. 671686.

Suarni, \& Marlina. (2018). Pengaruh Sosialisasi Perpajakan, Kualitas Pelayanan Pajak dan Tarif Pajak terhadap Kepatuhan Wajib Pajak Orang Pribadi di KPP Pratama Padang Satu. Jurnal Ekonomi , 1-14.

Sugiyono. (2016). Metode Penelitian Kuantitatif, Kualitatif dan $R \&$ D (Cetakan ke 23). Bandung: Alfabeta.

Tawas, V. B., Poputra, A. T., \& Lambey, R. (2016). Pengaruh Sosialisasi Perpajakan, Tarif Pajak dan Sanksi Perpajakan terhadap Kepatuhan Wajib Pajak Pelaporan SPT Tahunan Wajib Pajak Orang Pribadi. Jurnal EMBA, ISSN: 2303-1174 Vol. 4 No. 4 Desember 2016 Hal. 912- 921.

Tene, J. H., Sondakh, J. J., \& Warongan, J. D. (2017). Pengaruh Pemahaman Wajib Pajak, Kesadaran Pajak, Sanksi Perpajakan dan Pelayanan Fiskus terhadap Kepatuhan Wajib Pajak. Jurnal Emba, ISSN: 2303-1174 Vol. 5 No. 2 Juni 2017 Hal. 443-453.

Undang-undang No. 16 Tahun 2009 tentang Perubahan ke empat atas Undangundang Nomor 6 Tahun 1983 tentang Ketentuan Umum dan Tata Cara Perpajakan.

* Corresponding author's e-mail: dosen01058@unpam.ac.id http://openjournal.unpam.ac.id/index.php/JABI 